\title{
PEMAHAMAN MAHASISWA PPKN ANGKATAN 2010 DALAM PERKULIAHAN ANTHROPOLOGI BUDAYA MENURUT ANALISA TAKSONOMI BLOOM SEBAGAI UPAYA PERBAIKAN PEMBELAJARAN KOOPERATIF BAGI MAHASISWA DAN DOSEN
}

\author{
Bernadetta Budi Lestari \\ Prodi PKn Universitas PGRI Adi Buana Surabaya \\ bernadettabudilestari@yahoo.com
}

\begin{abstract}
Abstak
Pemahaman mahasiswa dalam belajar perlu ditingkatkan sedini mungkin agar mahasiswa tidak terlena dengan budaya santai. Mahasiswa PPKN angkatan 2010, yang sekarang ada pada posisi semester 3 perlu disemangati di dalam sistem pembelajarannya supaya mendapatkan prestasi tinggi, agar tidak kecewa di kemudian hari. Taksonomi Bloom merupakan salah satu analisa paling tepat di dalam mengamati hasil belajar siswa, untuk bisa mencapai nilai maksimal. Agar mendapatkan kepuasan hati dalam mencapai hasil belajar. Untuk bisa mencapai nilai yang baik maka proses PBM harus dijalankan secara kooperatif, agar pembelajaran di kelas menjadi hidup dan semarak. Untuk itu perlu perbaikan cara mengajar dosen dan perbaikan dalam belajar siswa. Apabila siswa aktif maka akan tercapai seluruh tujuan pembelajaran. Penelitian ini bertujuan untuk perbaikan pengajaran dosen dan belajarnya mahasiswa, karena pengajaran dosen bagus kalau cara belajar siswa jelek, maka PBM dinyatakan tidak berhasil, tetapi pengajaran yang kurang bagus, apabila mahasiswa memiliki cara belajar yang baik bisa jadi hasilnya baik. Tetapi alangkah baiknya jika pengajarannya bagus, kemudian cara belajar mahasiswa bagus maka tentu akan didapat nilai yang bagus.
\end{abstract}

Kata Kunci: Pemahaman mahasiswa dalam belajar, Analisa Taksonomi Bloom, Upaya pembelajaran kooperatif bagi mahasiswa, Pengajaran Dosen.

\section{PENDAHULUAN}

Kondisi Perkuliahan selama ini masih menunjukkan bahwa masih banyak Dosen kurang melakukan pembelajaran yang kurang tepat, sekedar memberi kuliah, kurang melakukan bimbingan pembelajaran. Pokok mahasiswa aktif kuliah, aktif mengerjakan tugas, mengikuti UTS, UAS sudah cukup. Padahal ilmu praktis yang didapatnya kurang. Tantangan terhadap peningkatan mutu, relevansi dan efektifitas Perkuliahan sangat penting untuk mebekali mahasiswa agar aktif dan kreatif. Agar tidak sekedar menerima apa yang diberikan dosen saja, melainkan mahasiswa wajib mengembangkan pengetahuan yang diberikan dosen melalui belajar aktif, baik di dalam perkuliahan maupun di luar perkuliahan agar mendapatkan pengetahuan secara utuh.

Perkuliahan dapat dicapai dengan baik apabila direncanakan oleh 
Dosen sebaik-baiknya, dalam bentuk silabi, Col, dan SAP, Untuk itu dosen dituntut aktif mempersiapkan perangkat tersebut dan juga dilengkapi media pembelajaran yang berlaku sekarang ini. Untuk itu Dosen harus mampu dan trampil memilih dan menggunakan metode mengajar untuk diterapkan dalam system pembelajaran yang efektif. Usaha utama yang dapat dilakukan oleh Dosen adalah melalui program pendidikan bagi para mahasiswa.

Landasan teoretis sebagai alternatif pijakan dalam mengemas pembelajaran untuk pemahaman (learning for understanding) sekaligus dalam pengembangan kemampuan pemecahan masalah fisika adalah sebagai berikut. (1) Tiga wawasan berpikir dalam pembelajaran fisika: (1) to present subject matter is not teaching, (2) to store stuffaway in the memory is not learning (3) to memorize what is stored away is not proof of understanding (Nachtigall, 1998:1).

Pemecahan masalah (problem solving) adalah upaya individu atau kelompok untuk menemukan jawaban berdasarkan pemahaman yang telah dimiliki sebelumnya dalam rangka memenuhi tuntutan situasi yang tak lumrah (Krulik \& Rudnick, 1996).Jadi aktivitas pemecahan masalah diawali dengan konfrontasi dan berakhir apabila sebuah jawaban telah diperoleh sesuai dengan kondisi masalah.Perkuliahan berbasis pemecahan masalah menjadi sangat penting, karena dalam belajar, peserta didik cepat lupa jika hanya dijelaskan secara lisan, mereka ingat jika diberikan contoh, dan memahami jika diberikan kesempatan mencoba memecahkan masalah (Steinbach, 2002).

Tujuan pendidikan dibagi ke dalam tiga domain, yaitu:

1. Cognitive Domain (Ranah Kognitif), yang berisi perilaku-perilaku yang menekankan aspek intelektual, seperti pengetahuan, pengertian, dan keterampilan berpikir.

2. Affective Domain (Ranah Afektif) berisi perilaku-perilaku yang menekankan aspek perasaan dan emosi, seperti minat, sikap apresiasi, dan cara penyesuaian diri.

3. Psychomotor Domain (Ranah Psikomotor) berisi perilaku-perilaku yang menekankan aspek keterampilan motorik seperti tulisan tangan, mengetik, berenang, dan mengoperasikan mesin.

\section{METODE PENELITIAN}

Rancangan penelitian ini untuk mengetahui ada tidaknya perbedaan penggunaan metode cooperative Tipe investigasi, dengan cara belajar mahasiswa PPKN A maupun B yang baik. Penelitian ini menggunakan penelitian eksperimen. Variabel-variabel yang diteliti dalam penelitian ini adalah (1) variabel pembelajaran cooperative Tipe investigasi dan (2)Cara belajar mahasiswa yang baik. (3) variabel moderator yaitu motivasi belajar, dan (4) 
variabel terikat adalah hasil belajar PPKN.

Perhatian utama dalam penelitian ini adalah keberhasilan belajar pada skala kelas.Keberhasilan populasi ini dicerminkan oleh nilai rata-rata yang diperoleh seluruh mahasiswa dan frekuensi nilai-nilai yang ada. Surakhmad (1990:100) memberi pedoman dalam pengambilan jumlah sampel yang sifat populasinya homogen, yaitu apabila jumlah populasi di bawah 100 dapat digunakan sampel 50\% dan di atas 100 dapat dipergunakan sampel sebesar 15\%. Karena jumlah populasinya tidak besar maka diambil secara keseluruhan yaitu 160 .

Dan dalam penelitian ini alat pengumpulan data terdiri dari 2 (macam) yaitu angket dan tes, yaitu angket motivasi belajar dan tes hasil belajar.

\section{HASIL PENELITIAN}

Adapun data yang diperoleh sebagai sumber penelitian ini berupa pekerjaan mahasiswa dalam pengerjaan UTS adalah sebagai berikut.

\section{Klas A:}

Kategori Kognitif : 20 responden: 62\% Kategori Affective: 8 responden: 25\% Kategori Psikomotor: 4 Responden: 12\% Klas B:

Kategori Kognitif: 15 responden: 71\% Kategori Affective: 3 responden: 14\% Kategori Psikomotor: 3 responden: 14\%
Adapun hasil analisa pada UAS tidak ada perbedaan yang signifikan:

\section{Klas A}

Kategori Kognitif 21 responden: 65\%

Kategori Affective 8 responden: 21\%

Kategori Psikomotor 3 responden 9\%.

\section{Klas B}

Kategori kognitif 17 responden 80\%

Kategori Affective 2 responden 9\%

Kategori Psikomotor 2 responden 9\%

\section{PEMBAHASAN}

Dari data dalam pengerjaan UTS di atas, maka dapat dikatakan bahwa pemikiran mahasiswa, sangatlah dangkal sekali dalam memahami materi perkuliahan. Untuk itu dosen harus bekerja keras dalam menyampaikan pembelajaran, sekaligus harus banyak pengarahan.

Langkah harapan untuk pembelajaran dilakukan dengan harapan bahwa, pemahaman pada pengerjaan soal UAS, mahasiswa penalarannya bertambah.

Dari data tersebut di atas betulbetul keadaannya sangat memprehatinkan, terlebih kalo melihat kehadiran mahasiswa NTT. Mereka mayoritas masuk dalam kategori penalaran yang paling rendah.

Di Klas A, 7 responden asal NTT, masuk dalam alternative Kognitive, Sedang Klas B, 13 responden 10, pada posisi Kategori kognitive, 2 responden pada kategori affective, dan 1 responden pada kategori Psikhomotor. 
Melihat kenyataan di atas, pengajaran dianggapnya sudah cukup sebenarnya peneliti tidak puas sampai di sini, tentu ingin melaksanakan banyak hal lagi, terutama dalam masalah pembelajaran. Ingin rasanya peneliti melakukan banyak hal agar mahasiswa menjadi pandai betul dan memiliki penalaran yang cukup kuat. Tapi karna keterbatasan waktu maka hal ini terkendala.

\section{SIMPULAN}

Pemahaman mahasiswa PPKN 2010 dalam menerima pembelajaran Antropologi, menurut taxonomi Bloom adalah sebagai berikut. Baik mahasiswa PPKN 2010 baik kelas A maupun kelas B mayoritas masih dalam tahap pemikiran oqnitif. Sedangkan yang pada tahap Afiqtif dan Psikomotor dalam kondisi yang minim.

Sebenarnya Pembelajaran Antropologi Budaya telah dilakukan secara Kooperatif oleh Dosen dengan wujud pembentukan kelompokkelompok Belajar baik di kelas A maupun kelas B dengan memberikan Tugas untuk memecahkan beberapa problema Pembelajaran Antropologi. Namun untuk kelas B praktek Pembelajaran Kooperatif belum bisa jalan karena banyak mahasiswa dengan status pekerja yang kurang aktif dalam perkuliahan.

Menurut anggapan Peneliti yang mengampu sebagai Dosen Antropologi Budaya dalam menyampaikan

baik. Yakni telah menyampaikan materi sesuai dengan Perencanaan yang terdapat dalam Silabus dan COL.

Menurut anggapan peneliti mahasiswa PPKN 2010 baik kelas A maupun kelas B pada umumnya belajar hanya disaat menjelang UTS dan UAS. Dengan demikian bisa dikatakan bahwa mahasiswa kelas A, maupun kelas B belum menempatkan dirinya sebagai mahasiswa yang baik.

\section{DAFTAR PUSTAKA}

www.http://wikipedia.wiki.org//pengert ianpemahahan

www.http://wikipedia.wiki.org//pengert ianntaksonomibloom

www.http://wikipedia.wiki.org//ranahta ksonomibloom

Ardhana, W. 1996. Atribusi Terhadap Sebab-sebab Keberhasilan dan Kegagalan serta Kaitannya dengan Motivasi untuk Belajar, (Pidato Pengukuhan Guru Besar) Malang: PPS IKIP Malang.

Arikunto. Suharsimi, 2002. Prosedur Penelitian Suatu Pendekatan Praktis. Jakarta : Rineka Cipta.

Azizah, Utiya. 1998. Penerapan Pembelajaran Kooperatif di Dalam Kelas (Suatu Pemikiran). Media Pendidikan dan Ilmu Pengetahuan No. 1/XX Surabaya: Universitas Pers IKIP Surabaya. 
Degeng, Nyoman S. 1989. Ilmu

Pengajaran Taksonomi variable. Jakarta: Dikti P2LPTK.

Santoso, Barokah. 1999. Cooperative Learning: Penerapan Teknik Jigsaw Dalam Pembelajaran. Gentengkali Jurnal Edisi II: Kanwil Depdikbud Propinsi Jawa Timur.

Sardiman. 2001. Interaksi dan Motivasi belajar Mengajar. Jakarta: PT. Raja Grafindo Persada.

Winkel. W.S. 1993. Psikologi Pendidikan dan Evaluasi Belajar. Jakarta: Gramedia. 